\title{
ESTAQUIA SEMILENHOSA E COMPARAÇÃO DE METABÓLITOS SECUNDÁRIOS EM Mikania glomerata SPRENGEL E Mikania laevigata SCHULTZ BIP EX BAKER
}

\author{
SEMILIGNEUOS STAKING AND COMPARISON OF SECONDARY \\ METABOLITS IN Mikania glomerata SPRENGEL AND Mikania laevigata \\ SCHULTZ BIP EX BAKER
}

\author{
Narumi Pereira LIMA \\ Orientador(a): Prof. Dr. Luiz Antonio BIASI \\ (Departamento de Fitotecnia e Fitossanitarismo)
}

\begin{abstract}
RESUMO
Visando a obtenção de subsídios técnicos à produção em escala comercial do guaco, o objetivo geral do presente estudo foi otimizar o processo de propagação via estaquia do guaco, e os objetivos específicos foram analisar fitoquimicamente a possibilidade do uso de Mikania laevigata como sucedânia de Mikania glomerata, determinar a área foliar, o tempo de imersão em água, o substrato e o sistema de irrigação mais indicados na estaquia de guaco e comparar agronomicamente o rendimento a campo das duas espécies. Foram realizado três experimentos de estaquia, para verificar o efeito da área foliar, do tempo de imersão da base da estaca em água e da interação substrato $x$ sistema de irrigação na estaquia das duas espécies de guaco. No primeiro experimento, foram testadas as seguintes áreas foliares: $0,5,25,50 \mathrm{e} 100 \mathrm{~cm}^{2}$. No segundo experimento, testou-se os substratos casca de arroz carbonizada, areia e solo, cada qual sob dois diferentes sistemas de irrigação (nebulização ou rega manual). No terceiro experimento, testou-se $0,3,6,12$ e 24 horas de imersão em água. Para todos os experimentos, utilizou-se estacas com $12 \mathrm{~cm}$ de comprimento, diâmetro de 0,8 a $1,0 \mathrm{~cm}$, retiradas da parte mediana dos ramos; o delineamento foi em blocos ao acaso, com quatro repetições e vinte estacas por parcela. A avaliação foi feita, respectivamente, 75,60 , e 90 dias após a instalação dos experimentos. O aumento da área foliar causou aumento no enraizamento e decréscimo na mortalidade das duas espécies, cabendo ressaltar que $M$. glomerata apresentou menor desenvolvimento que M. laevigata. Quanto à interação substrato x sistema de irrigação, constatou-se que, de modo geral, tanto para M. glomerata quanto para M. laevigata, o substrato casca de arroz carbonizada sob rega manual apresentou melhores resultados. O tempo de imersão da base da estaca em água não afetou significativamente, para ambas as espécies, nenhuma das variáveis. No estudo visando comparar o rendimento a campo das duas espécies, foram plantas mudas na Fazenda Experimental do Cangüiri da Universidade Federal do Paraná (UFPR), em 25/11/98, em covas espaçadas de 1,0 m na linha e de 2,0 m na entrelinha, com condução em espaldeira com fios a $0,8,1,2$ e 1,6 m de altura. O delineamento foi em blocos casualizados, com três repetições e três plantas por parcela. $A$ ocorrência de uma forte geada no inverno de 1999 causou a morte das plantas de M. glomerata. O rendimento de M. laevigata, avaliado 17 meses após o plantio, resultou em $501,5 \mathrm{~g}$ de matéria seca/planta. Também foi realizada a avaliação e comparação fitoquímica dos metabólitos secundários das duas espécies, no Laboratório de Fitoquímica da Faculdade de Farmácia da UFPR, utilizando os extratos hidroalcoólico e aquoso obtidos a partir de folhas e ramos estabilizados e triturados de plantas coletadas na Fazenda Experimental do Cangüiri da UFPR. Foram testados no extrato hidroalcoólico: características organolépticas, \% de extrato seco, alcalóides, cumarinas, flavonóides, antraquinonas, esteróides/triterpenóides, aminogrupos e leucoantocianidinas; no extrato aquoso: características organolépticas, \% extrato seco, taninos, glicosídeos cianogenéticos, saponinas, antocianidinas, ácidos fixos e voláteis e aminogrupos. M. glomerata apresentou resultados positivos para: cumarinas, esteróides/triterpenóides, saponinas e ácidos voláteis; cor verde escura, odor aromático adocicado, sabor amargo, $\mathrm{pH} 6,5$ e resíduo seco de $14,85 \%$ para o extrato hidroalcoólico e cor marrom escuro, odor herbáceo adocicado, sabor amargo e pH 5,0 e resíduo seco de 8,93\% para o extrato aquoso. $M$. laevigata apresentou resultados positivos para: cumarinas, esteróides/triterpenóides, aminogrupos, taninos e saponinas; cor verde escura, odor aromático adocicado, sabor amargo, $\mathrm{pH}$ 6,0 e resíduo seco de 6,94\% para o extrato hidroalcoólico e cor marrom escura, odor herbáceo adocicado, sabor amargo, pH 5,5 resíduo seco de 11,61\% para o extrato aquoso. Para ambas as espécies, os resultados, de modo geral, coincidem com os encontrados na literatura. Com base nestes estudos, conclui-se que: é possível a utilização de $M$. laevigata como sucedânea de $M$. glomerata; na propagação via estaquia de guaco, recomenda-se área foliar de $100 \mathrm{~cm}^{2}$ e uso da casca de arroz carbonizada, sob rega manual, como substrato; não houve influência do tempo de imersão da base da estaca em água; $M$. glomerata apresentou menor tolerância ao frio que $\mathrm{M}$. laevigata, sendo que esta apresentou produção de $501,5 \mathrm{~g}$ de matéria seca/planta.
\end{abstract}

Palavras-chave: guaco, propagação vegetativa, planta medicinal. 


\begin{abstract}
Seeking to the obtein technical subsides to the production in commercial scale of the "guaco", the general objective of the presente study was optimizing the propagation process through cuttings of the "guaco", and the specific objectives were to analyze phytochemically the possible use of the Mikania laevigata as succedaneous of Mikania glomerata, to determinate the leaf area, the time of immersion in water, the substratum and the irrigation system indicated in the cuttings of "guaco" and to comparate the yielding of the two species in the field. Three cuttings experiments were accomplished, to verify the effect of the leaf area, the time of immersion of the base of the cuttings in water and of the interaction substratum $x$ irrigation system in the cutting of the two "guaco" species. In the first experiment, the following leaves area were tested: $0,5,25,50$ and $100 \mathrm{~cm}^{2}$. In the second experiment was tested the following substratum: carbonized rice seed coat, sands and soil, each one under two different irrigation systems (nebulization or manual irrigation). In the third experiment, it was tested $0,3,6,12$ and 24 hours of immersion in water. For all the experiments, it was used cuttings with $12 \mathrm{~cm}$ of length, diameter of 0,8 to $1,0 \mathrm{~cm}$, taking from the medium part of the branches; the experimental design is a randomized complet blokm with four replication and twenty cutting each plot. The evaluation was made, respectively, 75, 60 and 90 days after the installation of the experiments. The increase of the leaf area caused increase in the root system and a decrease in the mortality of the two species, fitting to stand out that M. glomerata presented smaller development of the radicial system than $\mathrm{M}$. laevigata. With relatioship to the interaction substratum $\mathrm{x}$ irrigation system, was verified that, in general, as for M. glomerata as for M. laevigata, the substratum carbonizes rice seed coat under manual irrigation presented the best results. The time of immersion of the base of the cuttings in water didn't affect significantly, for both species, none of the variables. In the study seeking to compare the yielding of two species, plantlets were planted in the Fazenda Experimental do Cangüiri of the Universidade Federal do Paraná (UFPR), in 11/25/1998, in space holes of 1,0 m in the line and 2,0 $\mathrm{m}$ between lines, with conduction in spalier with threads to $0,8,1,2$ and 1,6 $\mathrm{m}$ of heigth. The experimental design was a randomized complet books, with three replication and three plants each plot. The occurence of a strong frost in the winter of 1999 caused the death of the plants of M. glomerata. The yielding of M. laevigata, evaluated 17 months after the plantation, resulted in $501.5 \mathrm{~g}$ of dry matter/ plant. Also was accomplished the phytochemical evaluation and comparison of the secondary metabolites of the two species, in the Laboratório de Fitoquímica da Faculdade de Farmácia of the UFPR, using the hidroalcoholic and aqueous extracts obtained from stabilizes and triturated leaves and branchesform plants collected in the Fazenda Experimental do Canguiri of the UFPR. They were tested hidroalcoholic extract: sensorial caracteristics, \% dry extract, alkaloids, coumarins, flavonoids, antraquinons, steroids/triterpenoids, aminogroups and luecoantocyantocyanindins; in aqueous extract: sensorial caracteristics, \% dry extract, tannins, cyanigenic glycosids, saponins, anthocinains fixed and volatile acids and aminogroups. M. glomerata presented positive results for: coumarins, steroids/ triterpenoids, saponins and volatile acids; dark green color, sweetened aromatic scent, bitter flavour, pH 6,5n and dry residue if $14,85 \%$ for the hidroalcoholic extract and dark brown color, sweetened herbaceous scent, bitter flavour, $\mathrm{pH} 5,0$ and dry residue of $8,93 \%$ for the aqueous extract. M. laevigata presented positive results for coumarins, steroids/triterpenoids, aminogroups, tannins ans saponins; dark green color, sweetened aromatic scent, bitter flavour, $\mathrm{pH} 6,0$ and dry residue if 6,94\% for the hidroalcoholic extract and dark brown color, sweetened herbaceous scent, bitter flavour, $\mathrm{pH} 5,5$ and dry residue of $11,61 \%$ for the aqueous extract. For both species the results, in general, coincide with that in the literature. Based in the studies, it was concluded that: it is possible the use of $\mathrm{M}$. laevigata as succedaneous of M. glomerata; in the propagation through "guaco" cuttings, is recommended the leaf area of $100 \mathrm{~cm}^{2}$ and the use of the carbonized rice seed coat, under manual irrigation, as substratum; there was no influence of the time of immersion of the base of the cutting in water; M. glomerata presented smaller tolerance to the cold than M. laevigata, wich presented the production of $501,5 \mathrm{~g}$ of dry matter/ plant.
\end{abstract}

Key-words: 'guaco, vegetative propagation, medicinal plant. 